\title{
Compounds from the Fruits of the Popular European Medicinal Plant Vitex agnus-castus in Chemoprevention via NADP(H):Quinone Oxidoreductase Type 1 Induction
}

\author{
Shenghong Li, ${ }^{1}$ Shengxiang Qiu, ${ }^{2}$ Ping Yao, ${ }^{3}$ Handong Sun, \\ Harry H. S. Fong, ${ }^{4}$ and Hongjie Zhang ${ }^{5}$ \\ ${ }^{1}$ State Key Laboratory of Phytochemistry and Plant Resources in West China, Kunming Institute of Botany, \\ The Chinese Academy of Sciences, Kunming, Yunnan 650204, China \\ ${ }^{2}$ South China Botanical Garden, Chinese Academy of Sciences, 723 Xingke Road, Tianhe District, Guangzhou 510650, China \\ ${ }^{3}$ Division of Life Science, The Hong Kong University of Science and Technology, Clear Water Bay Road, Hong Kong \\ ${ }^{4}$ Department of Medicinal Chemistry and Pharmacognosy, College of Pharmacy, University of Illinois at Chicago, \\ 833 S. Wood Street, Chicago, IL 60612, USA \\ ${ }^{5}$ School of Chinese Medicine, Hong Kong Baptist University, 7 Baptist University Road, Kowloon Tong, Hong Kong
}

Correspondence should be addressed to Hongjie Zhang; zhanghj@hkbu.edu.hk

Received 30 January 2013; Accepted 5 March 2013

Academic Editor: Ludger Beerhues

Copyright (C) 2013 Shenghong Li et al. This is an open access article distributed under the Creative Commons Attribution License, which permits unrestricted use, distribution, and reproduction in any medium, provided the original work is properly cited.

As part of our continuing efforts in the search for potential biologically active compounds from medicinal plants, we have isolated 18 compounds including two novel nitrogen containing diterpenes from extracts of the fruits of Vitex agnus-castus. These isolates, along with our previously obtained novel compound vitexlactam A (1), were evaluated for potential biological effects, including cancer chemoprevention. Chemically, the nitrogenous isolates were found to be two labdane diterpene alkaloids, each containing an $\alpha, \beta$-unsaturated $\gamma$-lactam moiety. Structurally, they were elucidated to be $9 \alpha$-hydroxy-13(14)-labden-16,15-amide (2) and $6 \beta$-acetoxy- $9 \alpha$-hydroxy-13(14)-labden-15,16-amide (3), which were named vitexlactams B and C, respectively. The 15 known isolates were identified as vitexilactone (4), rotundifuran (5), 8-epi-manoyl oxide (6), vitetrifolin D (7), spathulenol (8), cisdihydro-dehydro-diconiferylalcohol-9-O- $\beta$-D-glucoside (9), luteolin-7-O-glucoside (10), 5-hydroxy-3,6,7,4'-tetramethoxyflavone (11), casticin (12), artemetin (13), aucubin (14), agnuside (15), $\beta$-sitosterol (16), $p$-hydroxybenzoic acid (17), and $p$-hydroxybenzoic acid glucose ester (18). All compound structures were determined/identified on the basis of $1 \mathrm{D}$ and/or 2D NMR and mass spectrometry techniques. Compounds 6, 8, 9, and 18 were reported from a Vitex spieces for the first time. The cancer chemopreventive potentials of these isolates were evaluated for $\mathrm{NADP}(\mathrm{H})$ :quinone oxidoreductase type 1 (QR1) induction activity. Compound 7 demonstrated promising QR1 induction effect, while the new compound vitexlactam (3) was only slightly active.

\section{Introduction}

Botanicals are widely used as either dietary supplements or herbal medicines throughout the world for the prevention and mitigation against various diseases or ailments. Among these botanicals are plants of the genus Vitex plants. Botanically, this genus was previously placed in the family of Verbenaceae but was recently revised as belonging to the family Lamiaceae, which itself was formerly known as the Labiatae. Vitex consists of about 250 species distributed worldwide, but mainly in the tropical and temperate zones [1]. A number of species (e.g., V. agnus-castus, V. trifolia, V. negundo, and $V$. rotundifolia) have been used as traditional medicinal plants. To date, more than 20 Vitex species have been investigated for chemical and biological properties, with approximately 200 compounds, mainly flavonoids, terpenoids, steroids, iridoids, and lignans, having been isolated and characterized [2].

Vitex agnus-castus Linn., is commonly known as the chaste tree, grows to a height of $2-3 \mathrm{~m}$, and is distributed in the Mediterranean Region, Central Asia, and Southern 
Europe [3]. It is also cultivated in the various regions including the United States [4]. The fruits of V. agnus-castus are popularly used as a phytomedicine in Europe for the treatment of female hormonal disorders [5-7]. The fruit extract is also used as an alternative phytotherapeutic agent in the treatment of mastalgia [8]. There has been extensive research conducted on this phytomedicine leading to a large library of published literature on the pharmacognosy, traditional uses, chemical constituents, biology/pharmacology, and clinical studies [9]. In a previous communication we reported the isolation, structure determination, and X-ray crystallographic analysis of a novel labdane diterpene lactam from the $n$-hexane extracts of the fruits of this plant [10]. Further phytochemical studies of both of the $n$-hexane and methanol extracts resulted in the isolation of two additional new labdane diterpene lactams (2-3) and fifteen known compounds (4-18). In this paper, we describe the isolation and structure characterization of the two new metabolites and the identification of the 15 known compounds, as well as evaluating their $\mathrm{NADP}(\mathrm{H})$ :quinone oxidoreductase type 1 (QR1) induction activity potentials.

\section{Materials and Methods}

2.1. General Experimental Procedures. All melting points were measured on an XRC-1 micromelting point apparatus and are uncorrected. 1D (one-dimensional) and 2D (twodimensional) NMR (nuclear magnetic resonance) experiments were performed either on a Bruker AM-400 or a Bruker DRX-500 spectrometer. Unless otherwise is specified, chemical shifts $(\delta)$ were expressed in ppm with reference to the solvent signals. FABMS (fast atom bombardment mass spectrometry) and HRFABMS (high resolution fast atom bombardment mass spectrometry) were taken on a VG Auto Spec-3000 or a Finnigan MAT 90 instrument. IR (infrared) spectra were recorded on a Bio-Rad FTS-135 spectrometer with $\mathrm{KBr}$ pellets. UV (ultraviolet) spectral data were obtained on a UV 210A spectrometer. Optical rotations were carried out on a HORIBA SEPA-300 High Sensitive Polarimeter or a Perkin-Elmer model 241 Polarimeter. Column chromatography was performed either on Si gel (silica gel) (200300 mesh, Qingdao Marine Chemical Inc., China), Si gel H (10-40 $\mu$, Qingdao Marine Chemical Inc., China), Diaion HP-20 (Shandong Lukang Pharmaceutical Co., Ltd., China), Chromatorex ODS (Fuji Silysia Chemical Corporation, Ltd., Japan), or Lichroprep Rp $\mathrm{p}_{18}$ gel (40-63 $\mu \mathrm{m}$, Merck, Darmstadt, Germany). Fractions were monitored by silica gel TLC (thin layer chromatography) $\left[\mathrm{CHCl}_{3}-\mathrm{Me}_{2} \mathrm{CO}\right.$ (chloroformacetone) $9: 1,8: 2,7: 3$, and spots were visualized by heating silica gel plates sprayed with $10 \% \mathrm{H}_{2} \mathrm{SO}_{4}$ in EtOH (ethanol).

2.2. Plant Material. The fruits of $V$. agnus-castus were purchased from Frontier Botanicals, Norway, IA, USA (Lot. No. 799. 0116).

2.3. Extraction and Isolation. Dried fruits of $V$. agnus-castus $(4077 \mathrm{~g})$ were milled and sequentially extracted with $n$ hexane $(3 \times 8 \mathrm{~L})$ for $28 \mathrm{~h}$ and $\mathrm{MeOH}$ (methanol) $(4 \times 9 \mathrm{~L})$ for $24 \mathrm{~h}$. The $n$-hexane extract was filtered and concentrated in vacuo to dryness to afford $200 \mathrm{~g}$ of a residue (part I). The $\mathrm{MeOH}$ extract was filtered, concentrated, and diluted with water $(2 \mathrm{~L})$, followed by partitioning with EtOAc (ethyl acetate) $(4 \times 3 \mathrm{~L})$. The organic layer was evaporated in vacuo to dryness to give $60 \mathrm{~g}$ of a residue (part II). The water-soluble fraction was chromatographed on a column of Diaion HP20 eluting with aqueous $\mathrm{MeOH}(30 \% \rightarrow 80 \% \rightarrow 100 \%)$. The $80 \% \mathrm{MeOH}-\mathrm{H}_{2} \mathrm{O}$ fraction was concentrated in vacuo to yield $48 \mathrm{~g}$ of a dry residue (part III).

2.3.1. Isolation. Part I ( $200 \mathrm{~g}$ ) was absorbed on $200 \mathrm{~g}$ of silica gel and chromatographed on a prepacked $(500 \mathrm{~g})$ silica gel column, eluting stepwise with $n$-hexane, $\mathrm{CHCl}_{3}$, $\mathrm{CHCl}_{3}-\mathrm{Me}_{2} \mathrm{CO} / 1: 1$, and $\mathrm{Me}_{2} \mathrm{CO}$. Compound 16 (27 mg) was crystallized from the $\mathrm{CHCl}_{3}$ fraction and compound 11 (336 mg) was crystallized from the $\mathrm{CHCl}_{3}-\mathrm{Me}_{2} \mathrm{CO} / 1: 1$ fraction. The remaining $\mathrm{CHCl}_{3}-\mathrm{Me}_{2} \mathrm{CO} / 1: 1$ eluate was filtered (40 g, net weight) and subjected to further chromatographic separation over a Chromatorex ODS column (eluent: $80 \% \mathrm{MeOH}-\mathrm{H}_{2} \mathrm{O}$ as eluents) and silica gel columns (using $n$-hexane- $\mathrm{CHCl}_{3} / 1: 2, n$-hexane-EtOAc/3:2, and $n$-hexane$\mathrm{Me}_{2} \mathrm{CO} / 2: 1$ as eluents) to provide compounds 1 (40 mg), 2 (4 mg), 3 (11 mg), 4 (25 mg), 5 (67 mg), 6 (6 mg), 7 (14 mg), 8 (14 $\mathrm{mg})$, and 13 (9 mg).

Part II $(60 \mathrm{~g})$ was absorbed on $100 \mathrm{~g}$ of silica gel and chromatographed on a prepacked $(300 \mathrm{~g})$ silica gel column, eluting with $\mathrm{CHCl}_{3}-\mathrm{Me}_{2} \mathrm{CO}(1: 0,9: 1,8: 2,7: 3,0: 1)$. Compound 12 (1.635 g) was crystallized from the $\mathrm{CHCl}_{3}$ $\mathrm{Me}_{2} \mathrm{CO} / 1: 0-9: 1$ fraction. Part of the $\mathrm{CHCl}_{3}-\mathrm{Me}_{2} \mathrm{CO} / 8: 2$ fraction $(0.810 \mathrm{~g})$ was further chromatographed on $\mathrm{RP}_{18}$ gel (100 g) with $40 \%$ aqueous $\mathrm{MeOH}$ as eluents to give compound 17 (125 mg).

Part III (48 g) was again chromatographed on a Chromatorex ODS column eluting with aqueous $\mathrm{MeOH}(30 \%)$ and over a silica gel column eluting with $\mathrm{CHCl}_{3}-\mathrm{MeOH}(3: 1)$, $\mathrm{CHCl}_{3}-\mathrm{MeOH}-\mathrm{H}_{2} \mathrm{O}(4: 1: 0.1)$, and EtOAc-MeOH $(12: 1)$ to yield compounds 9 (108 mg), 10 (23 mg), 14 (55 mg), 15 (60 mg), and 18 (15 mg).

\subsection{Structural Characterization of Novel Isolates}

2.4.1. Vitexlactam $B$ (2). White crystals, m.p. $162^{\circ} \mathrm{C}$, $\mathrm{C}_{20} \mathrm{H}_{33} \mathrm{NO}_{2} ;[\alpha]_{\mathrm{D}}^{23.5}+18.75^{\circ}$ ( c $0.2, \mathrm{CHCl}_{3}$ ); IR (KBr) $v_{\max }$ : $3473,3187,3055,2924,2682,1684,1648,1442,1379,1296$, $1254,1228,1140,1085,1057,1041,1018,972,962,943,909$, 832, 791, 777, $698 \mathrm{~cm}^{-1} ;{ }^{1} \mathrm{H}$ NMR $\left(500 \mathrm{MHz}, \mathrm{CDCl}_{3}\right) \delta 1.50$ $(1 \mathrm{H}, \mathrm{dd}, J=11.0,2.0 \mathrm{~Hz}, \mathrm{H}-5), 1.75(1 \mathrm{H}, \mathrm{m}, \mathrm{H}-8), 1.78(1 \mathrm{H}$, m, H-11a), 1.67 (1H, m, H-11b), $2.36(2 \mathrm{H}, b r \mathrm{t}, J=8.2 \mathrm{~Hz}$, $\left.\mathrm{H}_{2}-12\right), 6.69(1 \mathrm{H}, b r \mathrm{~s}, \mathrm{H}-14), 3.89\left(2 \mathrm{H}, b r \mathrm{~s}, \mathrm{H}_{2}-15\right), 0.88(3 \mathrm{H}$, d, $\left.J=6.6 \mathrm{~Hz}, \mathrm{H}_{3}-17\right), 0.85\left(3 \mathrm{H}, \mathrm{s}, \mathrm{H}_{3}-18\right), 0.80$ (3H, s, $\left.\mathrm{H}_{3}-19\right)$, $0.90\left(3 \mathrm{H}, \mathrm{s}, \mathrm{H}_{3}-20\right), 6.61\left(1 \mathrm{H}\right.$, br s, NH); ${ }^{13} \mathrm{C}$ NMR data, see Table 1; EIMS (electron impact mass spectrum) $m / z 319[\mathrm{M}]^{+}$ (81), 304 (7), 286 (8), 206 (7), 194 (19), 180 (100), 167 (75), 152 (11), 138 (47), 123 (17), 110 (81), 96 (86), 82 (58), 69 (72), 55 (97); HREIMS $\mathrm{m} / z$ found $319.2509[\mathrm{M}]^{+}$, calcd. (calculated) 319.2511. 
TABLE $1:{ }^{13} \mathrm{C}$ NMR data of compounds $\mathbf{1 - 7}\left(\mathrm{CDCl}_{3}, \delta\right.$ in ppm).

\begin{tabular}{|c|c|c|c|c|c|c|c|}
\hline Carbon & $1^{\mathrm{a}}$ & $2^{\mathrm{b}}$ & $3^{a}$ & $4^{\mathrm{a}}$ & $5^{\mathrm{a}}$ & $6^{\mathrm{a}}$ & $7^{\mathrm{b}}$ \\
\hline $\mathrm{C}-1$ & $33.7 \mathrm{t}$ & $32.5 \mathrm{t}$ & $33.7 \mathrm{t}$ & $33.8 \mathrm{t}$ & $33.9 \mathrm{t}$ & $36.5 \mathrm{t}$ & $25.9 \mathrm{t}$ \\
\hline C-2 & $18.8 \mathrm{t}$ & $18.7 \mathrm{t}$ & $18.6 \mathrm{t}$ & $18.9 \mathrm{t}$ & $18.7 \mathrm{t}$ & $20.7 \mathrm{t}$ & $19.4 \mathrm{t}$ \\
\hline C-3 & $43.8 \mathrm{t}$ & $41.7 \mathrm{t}$ & $43.6 \mathrm{t}$ & $43.9 \mathrm{t}$ & $43.7 \mathrm{t}$ & $42.3 \mathrm{t}$ & $39.4 \mathrm{t}$ \\
\hline$C-4$ & $33.9 \mathrm{~s}$ & $33.3 \mathrm{~s}$ & $34.0 \mathrm{~s}$ & $34.3 \mathrm{~s}$ & $34.8 \mathrm{~s}$ & $32.9 \mathrm{~s}$ & $34.6 \mathrm{~s}$ \\
\hline C-5 & $47.5 \mathrm{~d}$ & $46.2 \mathrm{~d}$ & $47.6 \mathrm{~d}$ & $48.0 \mathrm{~d}$ & $47.5 \mathrm{~d}$ & $46.3 \mathrm{~d}$ & $132.5 \mathrm{~s}$ \\
\hline C-6 & $70.6 \mathrm{~d}$ & $21.7 \mathrm{t}$ & $69.9 \mathrm{~d}$ & $70.1 \mathrm{~d}$ & $70.3 \mathrm{~d}$ & $21.0 \mathrm{t}$ & $66.2 \mathrm{~d}$ \\
\hline C-7 & $36.3 \mathrm{t}$ & $31.4 \mathrm{t}$ & $36.1 \mathrm{t}$ & $36.4 \mathrm{t}$ & $36.1 \mathrm{t}$ & $37.9 \mathrm{t}$ & $72.7 \mathrm{~d}$ \\
\hline C-8 & $32.1 \mathrm{~d}$ & $36.8 \mathrm{~d}$ & $31.9 \mathrm{~d}$ & $32.3 \mathrm{~d}$ & $33.6 \mathrm{~d}$ & $74.1 \mathrm{~s}$ & $36.4 \mathrm{~d}$ \\
\hline C-9 & $76.4 \mathrm{~s}$ & $76.8 \mathrm{~s}$ & $76.7 \mathrm{~s}$ & $76.8 \mathrm{~s}$ & $76.8 \mathrm{~s}$ & $61.2 \mathrm{~d}$ & $42.9 \mathrm{~s}$ \\
\hline C-10 & $44.0 \mathrm{~s}$ & $43.3 \mathrm{~s}$ & $43.8 \mathrm{~s}$ & $44.1 \mathrm{~s}$ & $43.7 \mathrm{~s}$ & $38.9 \mathrm{~s}$ & $141.5 \mathrm{~s}$ \\
\hline C-11 & $32.3 \mathrm{t}$ & $32.0 \mathrm{t}$ & $32.3 \mathrm{t}$ & $31.9 \mathrm{t}$ & $31.8 \mathrm{t}$ & $18.6 \mathrm{t}$ & $29.3 \mathrm{t}$ \\
\hline C-12 & $21.7 \mathrm{t}$ & $22.0 \mathrm{t}$ & $26.5 \mathrm{t}$ & $25.7 \mathrm{t}$ & $21.5 \mathrm{t}$ & $45.1 \mathrm{t}$ & $38.6 \mathrm{t}$ \\
\hline C-13 & $140.6 \mathrm{~s}$ & $140.8 \mathrm{~s}$ & $163.6 \mathrm{~s}$ & $171.3 \mathrm{~s}$ & $125.5 \mathrm{~s}$ & $73.6 \mathrm{~s}$ & $73.0 \mathrm{~s}$ \\
\hline C-14 & $137.1 \mathrm{~d}$ & $136.9 \mathrm{~d}$ & $121.2 \mathrm{~d}$ & $115.3 \mathrm{~d}$ & $110.8 \mathrm{~d}$ & $146.1 \mathrm{~d}$ & $144.5 \mathrm{~d}$ \\
\hline C-15 & $46.6 \mathrm{t}$ & $46.4 \mathrm{t}$ & $175.3 \mathrm{~s}$ & $171.3 \mathrm{~s}$ & $142.9 \mathrm{~d}$ & $111.1 \mathrm{t}$ & $112.1 \mathrm{t}$ \\
\hline C-16 & $175.3 \mathrm{~s}$ & $175.8 \mathrm{~s}$ & $50.5 \mathrm{t}$ & $73.4 \mathrm{t}$ & $138.5 \mathrm{~d}$ & $27.4 \mathrm{q}$ & $27.8 \mathrm{q}$ \\
\hline C-17 & $16.4 \mathrm{q}$ & $16.6 \mathrm{q}$ & $16.0 \mathrm{q}$ & $16.3 \mathrm{q}$ & $16.1 \mathrm{q}$ & $32.0 \mathrm{q}$ & $11.1 \mathrm{q}$ \\
\hline C-18 & $33.6 \mathrm{q}$ & $33.7 \mathrm{q}$ & $33.6 \mathrm{q}$ & $33.8 \mathrm{q}$ & $33.6 \mathrm{q}$ & $33.1 \mathrm{q}$ & $29.3 \mathrm{q}$ \\
\hline C-19 & $23.7 \mathrm{q}$ & $22.1 \mathrm{q}$ & $23.6 \mathrm{q}$ & $23.9 \mathrm{q}$ & $23.7 \mathrm{q}$ & $21.3 \mathrm{q}$ & $28.1 \mathrm{q}$ \\
\hline C-20 & $18.9 \mathrm{q}$ & $16.2 \mathrm{q}$ & $19.0 \mathrm{q}$ & $19.2 \mathrm{q}$ & $19.0 \mathrm{q}$ & $24.7 \mathrm{q}$ & $28.0 \mathrm{q}$ \\
\hline $\mathrm{OAc}$ & $170.5 \mathrm{~s}$ & & $170.3 \mathrm{~s}$ & $170.6 \mathrm{~s}$ & $170.7 \mathrm{~s}$ & & 170.8 \\
\hline$(\mathrm{C}=\mathrm{O})$ & & & & & & & $(2 \mathrm{C}, \mathrm{s})$ \\
\hline OAc & $21.9 \mathrm{q}$ & & $21.8 \mathrm{q}$ & $22.1 \mathrm{q}$ & $21.9 \mathrm{q}$ & & $21.4 \mathrm{q}$ \\
\hline$\left(\mathrm{CH}_{3}\right)$ & & & & & & & $20.9 \mathrm{q}$ \\
\hline
\end{tabular}

${ }^{\mathrm{a}}$ Recorded at $100 \mathrm{MHz}$.

${ }^{\mathrm{b}}$ Recorded at $125 \mathrm{MHz}$.

2.4.2. Vitexlactam $C$ (3). White crystals, m.p. $178^{\circ} \mathrm{C}$, $\mathrm{C}_{22} \mathrm{H}_{35} \mathrm{NO}_{4} ;[\alpha]_{\mathrm{D}}^{18.7}-12.73^{\circ}\left(c 0.55, \mathrm{CHCl}_{3}\right)$; IR (KBr) $v_{\max }$ : 3364, 3297, 2925, 2867, 1711, 1670, 1465, 1426, 1383, 1362, 1271, $1256,1228,1203,1152,1125,1097,1039,1024,977,953,916,849$, $819 \mathrm{~cm}^{-1} ;{ }^{1} \mathrm{H}$ NMR $\left(400 \mathrm{MHz}, \mathrm{CDCl}_{3}\right) \delta 1.31(1 \mathrm{H}, b r \mathrm{~d}, J=$ $13.2 \mathrm{~Hz}, \mathrm{H}-3 \mathrm{a}), 1.13$ (1H, dt, $J=2.7,13.2 \mathrm{~Hz}, \mathrm{H}-3 \mathrm{~b}), 1.58(1 \mathrm{H}, \mathrm{d}$, $J=2.0 \mathrm{~Hz}, \mathrm{H}-5), 5.35(1 \mathrm{H}, b r \mathrm{~d}, J=2.2 \mathrm{~Hz}, \mathrm{H}-6), 2.10(1 \mathrm{H}, \mathrm{m}$, $\mathrm{H}-8), 1.90$ (1H, m, H-11a), 1.72 (1H, m, H-11b), 2.43 (2H, m, $\left.\mathrm{H}_{2}-12\right)$, $5.82\left(1 \mathrm{H}\right.$, br s, H-14), $3.91\left(2 \mathrm{H}\right.$, br s, $\left.\mathrm{H}_{2}-16\right), 0.87(3 \mathrm{H}$, $\left.\mathrm{d}, J=6.7 \mathrm{~Hz}, \mathrm{H}_{3}-17\right), 0.93\left(3 \mathrm{H}, \mathrm{s}, \mathrm{H}_{3}-18\right), 0.97$ (3H, s, $\left.\mathrm{H}_{3}-19\right)$, 1.22 (3H, s, $\left.\mathrm{H}_{3}-20\right), 6.92$ (1H, br s, NH), 2.03 (3H, s, 6-OAc); ${ }^{13} \mathrm{C}$ NMR data, see Table 1; EIMS $m / z 377[\mathrm{M}]^{+}$(3), 317 (76), 302 (15), 284 (6), 260 (29), 242 (8), 222 (21), 202 (23), 187 (48), 167 (60), 150 (28), 133 (41), 119 (64), 110 (68), 96 (97), 83 (72), 69 (77), 55 (100); HREIMS $m / z$ found $377.2547[\mathrm{M}]^{+}$, calcd. 377.2566 .

2.5. Chemoprevention Evaluation: $N A D(P) H: Q u i n o n e ~ O x i-$ doreductase Type 1 (QR1) Assay. Test compounds were evaluated for their potential to induce quinone reductase type 1 (QR1) activity with Hepa 1clc7 cells. The cells were plated in 96-well plates at a density of $2 \times 10^{4}$ cells $/ \mathrm{mL}$ in $190 \mu \mathrm{L}$ of $\alpha$-MEM (minimum essential medium) containing 100 units/mL penicillin G sodium, $100 \mu \mathrm{g} / \mathrm{mL}$ streptomycin sulfate, and $250 \mathrm{ng} / \mathrm{mL}$ amphotericin B supplemented with $10 \%$ fetal bovine serum at $37^{\circ} \mathrm{C}$ in a $5 \% \mathrm{CO}_{2}$ atmosphere.
After preincubation for $24 \mathrm{~h}$, the medium was changed, and test compounds were added to afford a final concentration range of 2 to $20 \mu \mathrm{g} / \mathrm{mL}$, and then the cells were incubated for an additional $48 \mathrm{~h}$. The medium was decanted, and the cells were incubated with $50 \mu \mathrm{L}$ of $0.8 \%$ digitonin and 2 mM EDTA (ethylenediaminetetraacetic acid) solution ( $\mathrm{pH}$ 7.8) at $37^{\circ} \mathrm{C}$ for $10 \mathrm{~min}$. Quinone reductase activity was determined by measuring the $\mathrm{NAD}(\mathrm{P}) \mathrm{H}$-dependent menadiol mediated reduction of MTT [3-(4, 5-dimethylthiazol2-yl)-2,5-diphenyltetrazolium bromide] to a blue formazan. Cytotoxicity was determined by crystal violet staining assay. Induction of QR activity was calculated by comparing the QR specific activity of agent-treated cells with that of vehicle solvent-treated cells. $4^{\prime}$-Bromoflavone with a CD value of $12.9 \mathrm{nM}$ was used as a positive control. CD represents the concentration of a test compound required to double QR induction in comparison with the vehicle control.

2.6. Supporting Information Available. NMR and MS data of the known compounds are available as Supplementary Material online at http://dx.doi.org/10.1155/2013/432829.

\section{Results and Discussion}

3.1. Plant Extracts and Isolation of Compounds. The purchased fruits of $V$. agnus-castus were milled and sequentially 


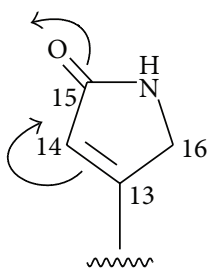

(a)

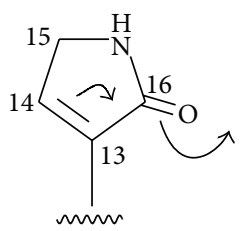

(b)

FIGURE 1: Electronic clouds movements of two different conjugated systems in compounds 3 (a) and 1 (b).

extracted with $n$-hexane and methanol. The $n$-hexane extract was successively chromatographed on silica gel and Chromatorex ODS to afford compounds 1-8, 11, 13, and 16. The methanol extract was partitioned between EtOAc and water. The EtOAc layer was chromatographed on silica gel to give compounds 12 and 17. The water-soluble fraction was chromatographed on columns of Diaion HP-20, Chromatorex ODS, and silica gel to yield compounds 9, 10, 14, 15, and 18 (Scheme 1).

\subsection{Structure Elucidation and Identification of Isolated Compounds}

3.2.1. Vitexlactam B (2). Vitexlactam B (2) was obtained as white crystals. EI mass spectrum showed strong molecular ion peak at $m / z 319[\mathrm{M}]^{+}$(81\% relative intensity), corresponding to a molecular formula of $\mathrm{C}_{20} \mathrm{H}_{33} \mathrm{NO}_{2}$, which was confirmed by high resolution EI mass spectrum (found: $\mathrm{m} / z$ 319.2509, calcd. 319.2511). The existence of a nitrogen atom was supported by its odd numbered molecular weight and a positive reaction to the Dragendorff reagent.

The ${ }^{1} \mathrm{H}$ and ${ }^{13} \mathrm{C}$ NMR (Table 1 ) spectra of 2 , being very similar to those of $\mathbf{1}$ [10], suggested that $\mathbf{2}$ is a closely related labdane diterpene alkaloid (Table 1), with an $\alpha, \beta$ unsaturated $\gamma$-lactam moiety at the C-9 side chain. 2 differed from 1 only by the absence of the signals for an acetyl group and the replacement of an oxygen-bearing methine at $\delta_{\mathrm{C}} 70.6$ by a methylene signal at $\delta_{\mathrm{C}} 21.7$, indicating that $\mathbf{2}$ is the 6-deacetoxy derivative of $\mathbf{1}$. The result was further supported by the facts that $\mathbf{1}$ was 58 atomic mass units less than 2 and the lack of an acetoxy group being observed in the IR spectrum of 2 . Full assignments of 2 using 2D NMR (including ${ }^{1} \mathrm{H}^{-1} \mathrm{H}$ COSY (correlation spectroscopy), HMQC (heteronuclear multiple-quantum correlation spectroscopy), HMBC (heteronuclear multiple bond correlation spectroscopy), and ROESY (rotating-frame Overhauser spectroscopy)) techniques established the structure of $\mathbf{2}$ to be the expected $9 \alpha$-hydroxy-13(14)-labden-16,15-amide. Compound $\mathbf{2}$ was accordingly identified as the deacetoxy derivative of $\mathbf{1}$ and was given the trivial name of vitexlactam $B$.

3.2.2. Vitexlactam C (3). Vitexlactam C (3) was also isolated as white crystals. EI mass spectrum under $70 \mathrm{eV}$ displayed a weak $[\mathrm{M}]^{+}$ion peak at $m / z 377(3 \%)$ identical with that of $\mathbf{1}$ in both the mass charge ratio and the relative intensity [11]. In addition, a strong fragment ion peak at $m / z 317$ (76\%) due to $[\mathrm{M}-\mathrm{AcOH}]^{+}$and a series of fragment ions similar to those for 1 were also observed. High resolution EI mass spectrum (found: $m / z$ 377.2547, calcd. 377.2566) established that both compounds have the same molecular formula of $\mathrm{C}_{22} \mathrm{H}_{35} \mathrm{NO}_{4}$. Therefore 3 was tentatively identified as an isomer of 1. Comparison of the ${ }^{1} \mathrm{H}$ and ${ }^{13} \mathrm{C}$ NMR (Table 1) spectra of $\mathbf{3}$ with those of $\mathbf{1}$ (Table 1) indicated that the two compounds were equivalent not only in their skeletons but also in their oxygenation patterns. NMR spectral differences between these two compounds are mainly due to the $\alpha, \beta$ unsaturated $\gamma$-lactam moieties in their C-9 side chains. The conjugate functionality occurred in $\mathbf{3}$ was deduced to be type (a) in contrast to type (b) in $\mathbf{1}$ (Figure 1). In the former conjugating system, C-13 is in a deshielded position while C14 and $\mathrm{H}-14$ are in a shielded position. On the contrary, in the latter (type (b)), C-13 is in a shielded position while C-14 and $\mathrm{H}-14$ are in a deshielded position. Accordingly, C-13 of 3 moved downfield from $\delta_{\mathrm{C}} 140.6(\mathrm{~s})$ in 1 to $\delta_{\mathrm{C}} 163.6(\mathrm{~s})$, and C-14/H-14 of 3 shifted upfield from $\delta_{\mathrm{C} / \mathrm{H}} 137.1(\mathrm{~d}) / 6.71(1 \mathrm{H}$, br s) in 1 to $\delta_{\mathrm{C} / \mathrm{H}} 121.2(\mathrm{~d}) / 5.82(1 \mathrm{H}, b r \mathrm{~s})$. 2D NMR analysis of 3 revealed that, unlike in $\mathbf{1}$, the ${ }^{1} \mathrm{H}-{ }^{1} \mathrm{H}$ COSY correlation between $\mathrm{H}-14$ and the nitrogen-bearing methylene at $\delta_{\mathrm{H}} 3.91$ (2H, br s) and the ${ }^{1} \mathrm{H}_{-}{ }^{13} \mathrm{C}$ interaction (Figure 2) between $\mathrm{H}_{2}$ $12\left[\delta_{\mathrm{H}} 2.44(2 \mathrm{H}, \mathrm{m})\right]$ and the lactam carbonyl carbon at $\delta_{\mathrm{C}}$ 175.3 (s) disappeared while ${ }^{1} \mathrm{H}_{-}{ }^{13} \mathrm{C}$ interaction between $\mathrm{H}_{2}$ 12 and the nitrogen-occurring methylene at $\delta_{\mathrm{C}} 50.5(\mathrm{t})$ were observed, thus confirming the presence of a type (a) conjugate functionality in 3. Other structural correlations, including key NOEs (nuclear Overhauser effects) (Figure 3) in 3, were identical with those in $\mathbf{1}$.

A detailed spectral comparison between 3 and vitexilactone (4) [11] was also carried out. The molecular weight of 3 is lower by 1 mass unit than that of $\mathbf{4}$. Besides, 3 differed from 4 (Table 1) mainly by the upfield shifted $\mathrm{H}_{2}-16$ and $\mathrm{C}$ 16 signals (from $\delta_{\mathrm{H} / \mathrm{C}} 4.77(2 \mathrm{H}, b r \mathrm{~d}, J=1.3 \mathrm{~Hz}$ ) $/ 73.4(\mathrm{t})$ in 4 to $\delta_{\mathrm{H} / \mathrm{C}} 3.94(2 \mathrm{H}$, br s $) / 50.5(\mathrm{t})$ in 3$)$ and the existence of an extra NH proton at $\delta_{\mathrm{H}} 6.92(1 \mathrm{H}, b r \mathrm{~s})$, indicating that an $\alpha, \beta$ unsaturated $\gamma$-lactam moiety in 3 took the place of the $\alpha, \beta$ unsaturated $\gamma$-lactone in 4 . Based on all the abovedescribed spectral features, compound 3 was consequently deduced to be $6 \beta$-acetoxy- $9 \alpha$-hydroxy-13(14)-labden-15,16-amide and was named vitexlactam $C$.

Considering that only mild conditions were employed and that no nitrogen containing solvents and chromatographic materials were involved in the entire extraction and separation procedures, we postulate that compounds 1-3 


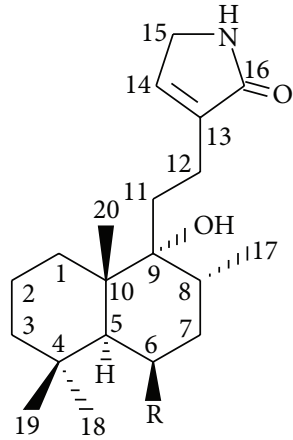

$1 \mathrm{R}=\mathrm{OAC}$

$2 \mathrm{R}=\mathrm{H}$

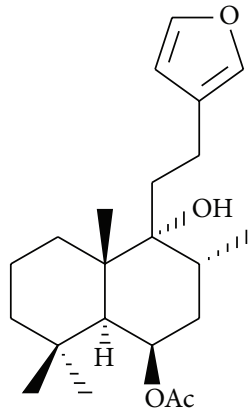

5

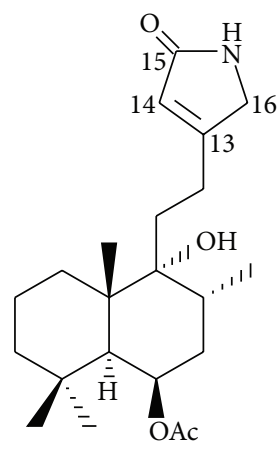

3

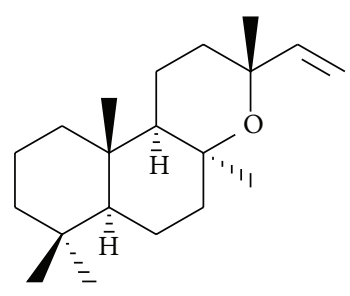

6

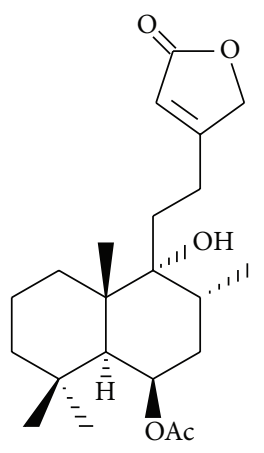

4<smiles>C=CC(C)(O)CC[C@]1(C)C2=C([C@H](OC(C)=O)[C@@H](OC(C)=O)[C@@H]1I)C(C)(C)CCC2</smiles><smiles>O=c1cc(-c2ccc(O)c(O)c2)oc2cc(Cl)cc(O)c12</smiles>

10<smiles>[R]c1cc(-c2oc3cc(OC)c(OC)c(O)c3c(=O)c2OC)ccc1OC</smiles>

$11 \mathrm{R}=\mathrm{H}$

$12 \mathrm{R}=\mathrm{OH}$

$13 \mathrm{R}=\mathrm{OCH}_{3}$<smiles>[R20]CC1=C[C@@H](O)[C@H]2C=CO[C@H](OCl)[C@H]12</smiles>

$14 \mathrm{R}=\mathrm{H}$

$15 \mathrm{R}=p$-hydroxybenzoyl<smiles>[R]OC(=O)c1ccc(O)cc1</smiles>

$17 \mathrm{R}=\mathrm{H}$

$18 \mathrm{R}=\mathrm{Glc}$ 


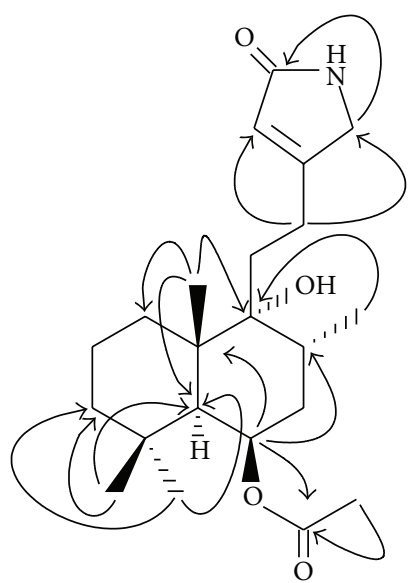

Figure 2: Key HMBC correlations of vitexlactam C (3).

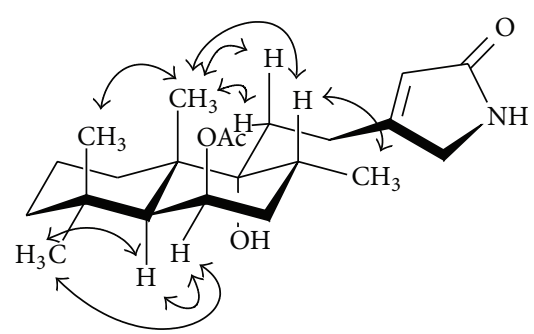

FIgURE 3: Key NOESY correlations of vitexlactam C (3).

are biogenetic amination products of their corresponding lactones (e.g., 3 was derived from $\mathbf{4}$ ).

3.2.3. Identification of Known Compounds. Along with the new compounds, fifteen known compounds were also isolated in the course of the current study. Through comparison of their ${ }^{1} \mathrm{H}$ and ${ }^{13} \mathrm{C}$ NMR and MS data with those values reported in the literature, they were identified as three labdane-type diterpenoids, vitexilactone (4) [11]; rotundifuran (5) [11], and 8-epi-manoyl oxide (6) $[12]\left([\alpha]_{\mathrm{D}}^{19.5}-11.8^{\circ} ; \mathrm{c}\right.$ $=0.55, \mathrm{CHCl}_{3}$ ); a rearranged labdane (halimane) diterpenoid, vitetrifolin $\mathrm{D}$ (7) [13]; an aromadendrene-type sesquiterpenoid, spathulenol (8) [14, 15]; a lignan glucoside, cisdihydro-dehydro-diconiferylalcohol-9-O- $\beta$-D-glucoside (9) [16]; four flavonoids, luteolin-7-O-glucoside (10) [17], 5hydroxy-3,6,7,4'-tetramethoxyflavone (11) [18], casticin (12) [19], and artemetin (13) [20]; two iridoid glycosides, aucubin (14) [21] and agnuside (15) [22]; a sterol, $\beta$-sitosterol (16) (comparison with an authentic sample); and two simple phenolics, $p$-hydroxybenzoic acid (17) [22] and $p$ hydroxybenzoic acid glucose ester (18) [22]. The occurrence of compounds 7-9 and 18 in the genus Vitex is being reported for the first time.

3.3. Activity Evaluation of the Isolated Compounds on QR1 Induction. These compounds have been evaluated for their potential chemopreventive activity by induction of the ubiquitous flavoenzyme $\mathrm{NADP}(\mathrm{H})$ :quinone oxidoreductase type 1 (QR1) with cultured Hepa 1clc7 cells. QR1 has been determined as an important phase II detoxification enzyme that can protect cells against the harmful effects caused by free radicals and reactive oxygen species by catalyzing the reduction of quinones to hydroquinones [23]. Hence, enhanced activity of the enzyme provides protection of cells from potential carcinogenicity. Vitetrifolin D (7) was shown to induce QR1 activity with a CD value of $23.2 \mu \mathrm{M}$. Although vitexlactam C (3) induced QR1 by 1.5 times that of the vehicle control at a concentration of $5.3 \mu \mathrm{M}$, it was toxic to Hepa 1clc7 cells with $57 \%$ inhibition of the cells at $26.5 \mu \mathrm{M}$. None of the other compounds demonstrated QR1 induction activity.

\section{Conclusion}

The fruits of Vitex agnus-castus have been popularly used as a phytomedicine in Europe, especially Germany, for the treatment of premenstrual stress syndrome. However, the evaluation of this herb or its phytochemical constituents for cancer chemoprevention activity has not been reported. Thus, we undertook a study of the 18 compounds we isolated from the fruits of this plant in a bioassay, which have been used for assessing chemoprevention potentials. The isolates, including several novel nitrogen containing labdane diterpenes, were thus evaluated for their potentials in the induction of the phase II detoxification enzyme QR1. Results showed that only the labdane compounds 3 and 7 demonstrated QR1 induction effect. We have demonstrated that compounds possessing potential chemopreventive action do exist in V. agnus-castus and that further phytochemical and biological investigations of this plant material coupled with structure modification studies are needed in order to discover additional/modified labdanes possessing more potent $\mathrm{QR} 1$ induction activity and chemopreventive potential.

\section{Conflict of Interests}

The authors have no conflict of interests with the trademarks included in the paper.

\section{Acknowledgments}

The authors thank the members of the analytical group of the State Key Laboratory of Phytochemistry Laboratory and Plant Resources in West China, Kunming Institute of Botany, Academic Sinica, for measurements of the NMR, MS, IR, UV, and ORD spectral data. This work was in part supported by the "Hundred Talents Program" of the Chinese Academy of Sciences (awarded to Dr. S. Li).

\section{References}

[1] "Delectis Florae Reipublicae Popularis Sinicae Agendae Academiae Sinicae Edita," in Flora Republicae Popularis Sinicae, vol. 65, pp. 131-150, Science Press, Beijing, 1982.

[2] S. H. Li, Studies on the chemical and biological constituents of three Taxaceae plants, Vitex agnus-castus and Isodon xerophilus [Ph.D. thesis], Kunming Institute of Botany, the Chinese Academy of Sciences, Kunming, Yunnan, China, 2001. 
[3] T. G. Tutin, V. H. Heywood, N. A. Burges, D. H. Valentine, S. M. Walters, and D. A. Webb, Flora Europaea, vol. 3, Cambridge University Press, Cambridge, UK, 1972.

[4] United States Department of Agriculture, "Vitex agnus-castus L," 2013, http://plants.usda.gov/java/profile?symbol=viag.

[5] S. Y. Mills, Out of the Earth: The Essential Book of Herbal Medicine, Viking Arkana, London, UK, 1991.

[6] S. Y. Mills, Woman Medicine: Vitex Agnus-Castus, the Herb, Amberwood, Christchurch, UK, 1992.

[7] K. P. Odenthal, "Vitex agnus castus L.- traditional drug and actual indications," Phytotherapy Research, vol. 12, no. 1, supplement, pp. S160-S161, 1998.

[8] A. R. Carmichael, "Can Vitex Agnus castus be used for the treatment of mastalgia? What is the current evidence?" EvidenceBased Complementary and Alternative Medicine, vol. 5, no. 3, pp. 247-250, 2008.

[9] G. S. Chhabra and K. S. Kulkarni, "Vitex agnus castus-an overview," Journal of Natural Remedies, vol. 11, no. 2, pp. 90-97, 2011.

[10] S. H. Li, H. J. Zhang, S. X. Qiu et al., "Vitexlactam A, a novel labdane diterpene lactam from the fruits of Vitex agnus-castus," Tetrahedron Letters, vol. 43, no. 29, pp. 5131-5134, 2002.

[11] H. Taguchi, "Studies on the constituents of Vitex cannabifolia," Chemical and Pharmaceutical Bulletin, vol. 24, no. 7, pp. 16681670, 1976.

[12] Y. S. Cheng and E. von Rudloff, "Two new diterpenoid oxides from the leaf oil of Chamaecyparis nootkatensis," Tetrahedron Letters, vol. 11, no. 14, pp. 1131-1132, 1970.

[13] M. Ono, Y. Ito, and T. Nohara, "Four new halimane-type diterpenes, vitetrifolins D-G, from the fruit of Vitex trifolia," Chemical and Pharmaceutical Bulletin, vol. 49, no. 9, pp. 12201222, 2001.

[14] R. C. Bowyer and P. R. Jefferies, "Structure of spathulenol," Chemistry \& Industry, no. 30, pp. 1245-1246, 1963.

[15] A. Ulubelen, G. Topcu, C. Eris et al., “Terpenoids from Salvia sclarea," Phytochemistry, vol. 36, no. 4, pp. 971-974, 1994.

[16] T. Satake, T. Murakami, Y. Saiki, and C. M. Chen, "Chemical and chemotaxonomic studies of genus Pteris and related genera (Pteridaceae)-19. Chemical studies of components of Petrisvittata L," Chemical \& Pharmaceutical Bulletin, vol. 26, no. 5, pp. 1619-1622, 1978.

[17] K. R. Markham, B. Ternai, R. Stanley, H. Geiger, and T. J. Mabry, "Carbon-13 NMR studies of flavonoids-III. Naturally occurring flavonoid glycosides and their acylated derivatives," Tetrahedron, vol. 34, no. 9, pp. 1389-1397, 1978.

[18] K. Sachdev and D. K. Kulshreshtha, "Flavonoids from Dodonaea viscosa," Phytochemistry, vol. 22, no. 5, pp. 1253-1256, 1983.

[19] E. Wollenweber and K. Mann, "Flavonols from fruits of Vitex agnus castus," Planta Medica, vol. 48, no. 2, pp. 126-127, 1983.

[20] Y. Kondo, K. Sugiyama, and S. Nozoe, "Studies on the constituents of Vitex rotundifolia L. fil," Chemical and Pharmaceutical Bulletin, vol. 34, no. 11, pp. 4829-4832, 1986.

[21] K. Gorler, D. Oehlke, and H. Soicke, "Iridoidglycoside in Vitex agnus-castus," Planta Medica, vol. 6, pp. 530-531, 1985.

[22] M. Tabata, Y. Umetani, M. Ooya, and S. Tanaka, "Glucosylation of phenolic compounds by plant cell cultures," Phytochemistry, vol. 27, no. 3, pp. 809-813, 1988.

[23] R. Li, M. A. Bianchet, P. Talalay, and L. M. Amzel, “The threedimensional structure of $\mathrm{NAD}(\mathrm{P}) \mathrm{H}$ :quinone reductase, a flavoprotein involved in cancer chemoprotection and chemotherapy: mechanism of the two-electron reduction," Proceedings of the National Academy of Sciences of the United States of America, vol. 92, no. 18 , pp. 8846-8850, 1995. 


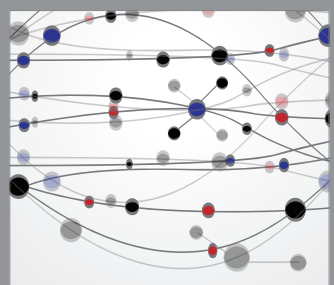

The Scientific World Journal
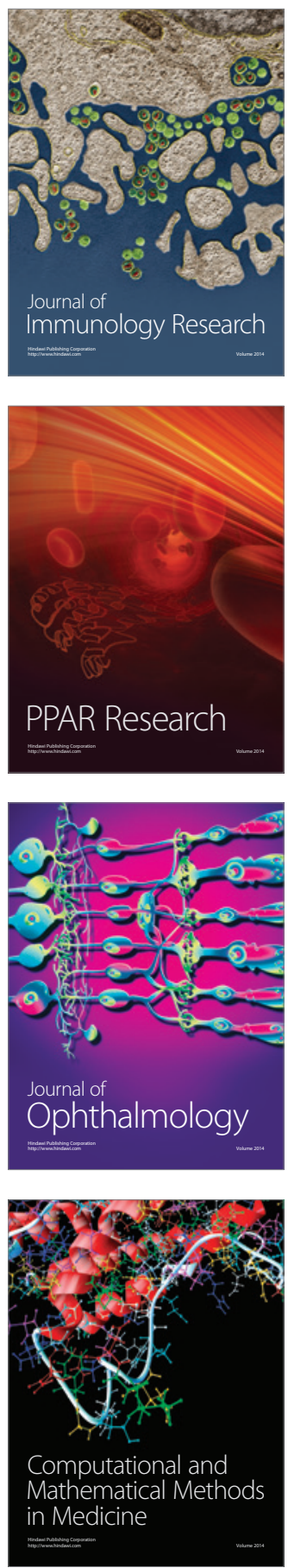

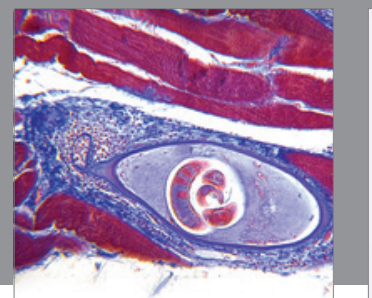

Gastroenterology

Research and Practice
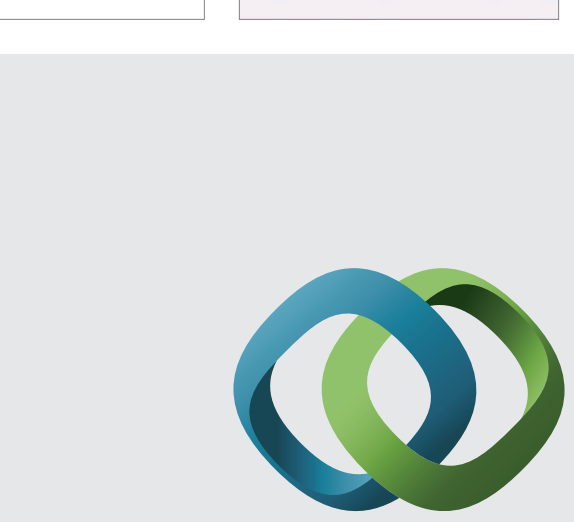

\section{Hindawi}

Submit your manuscripts at

http://www.hindawi.com
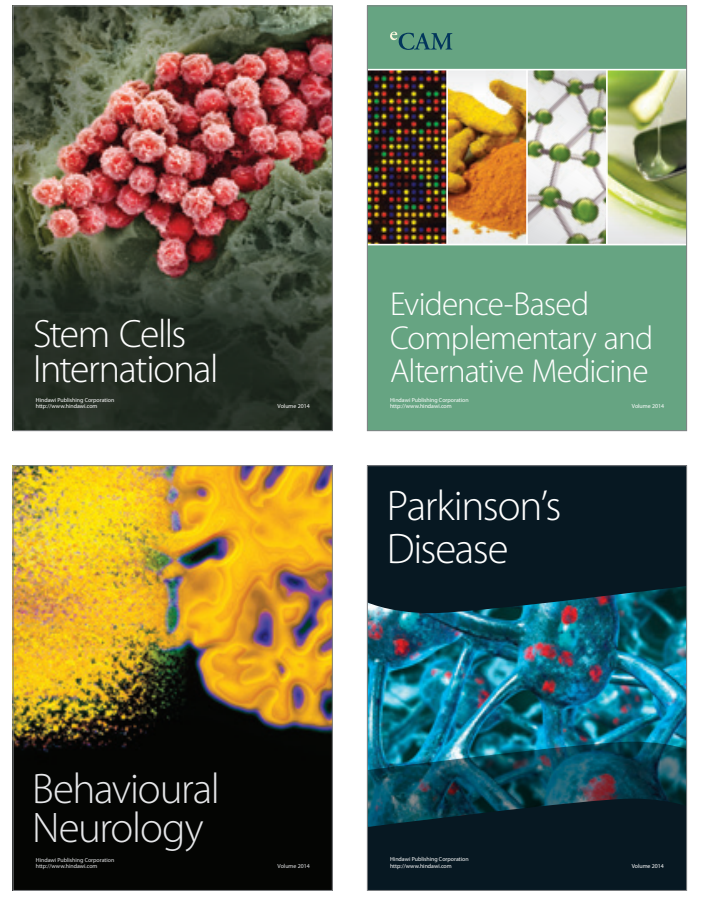
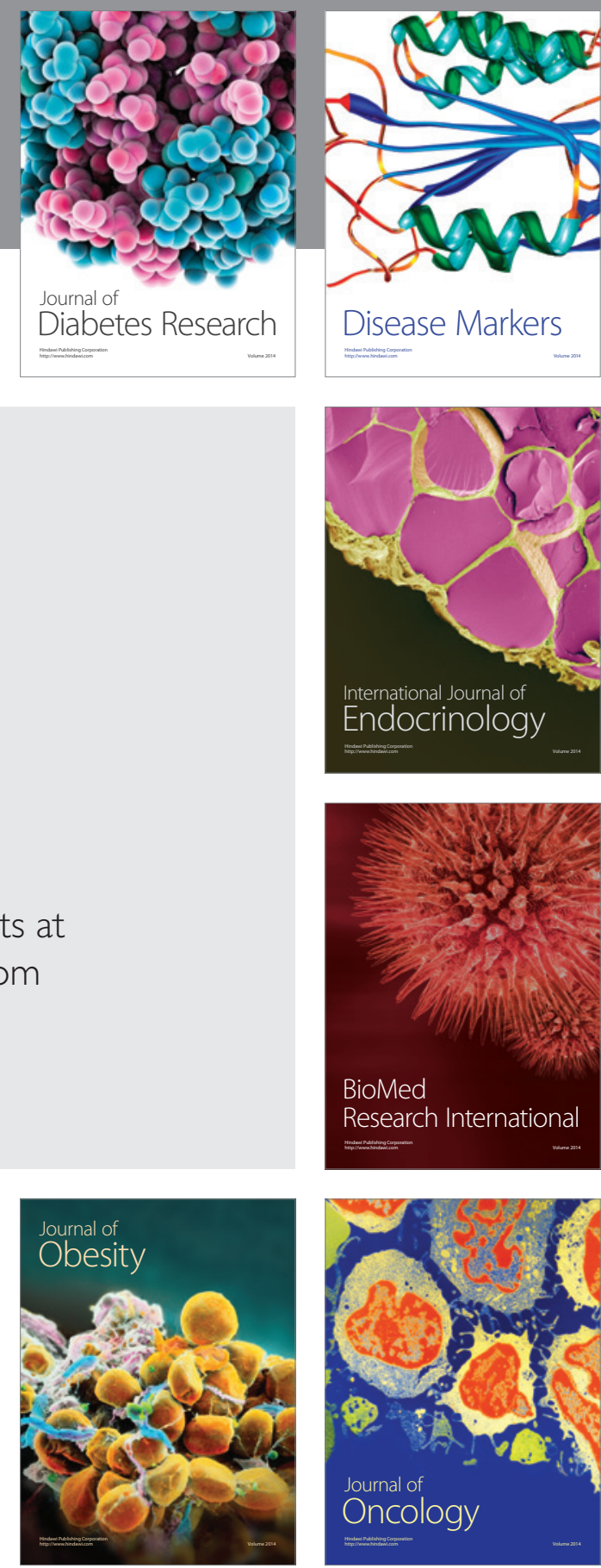

Disease Markers
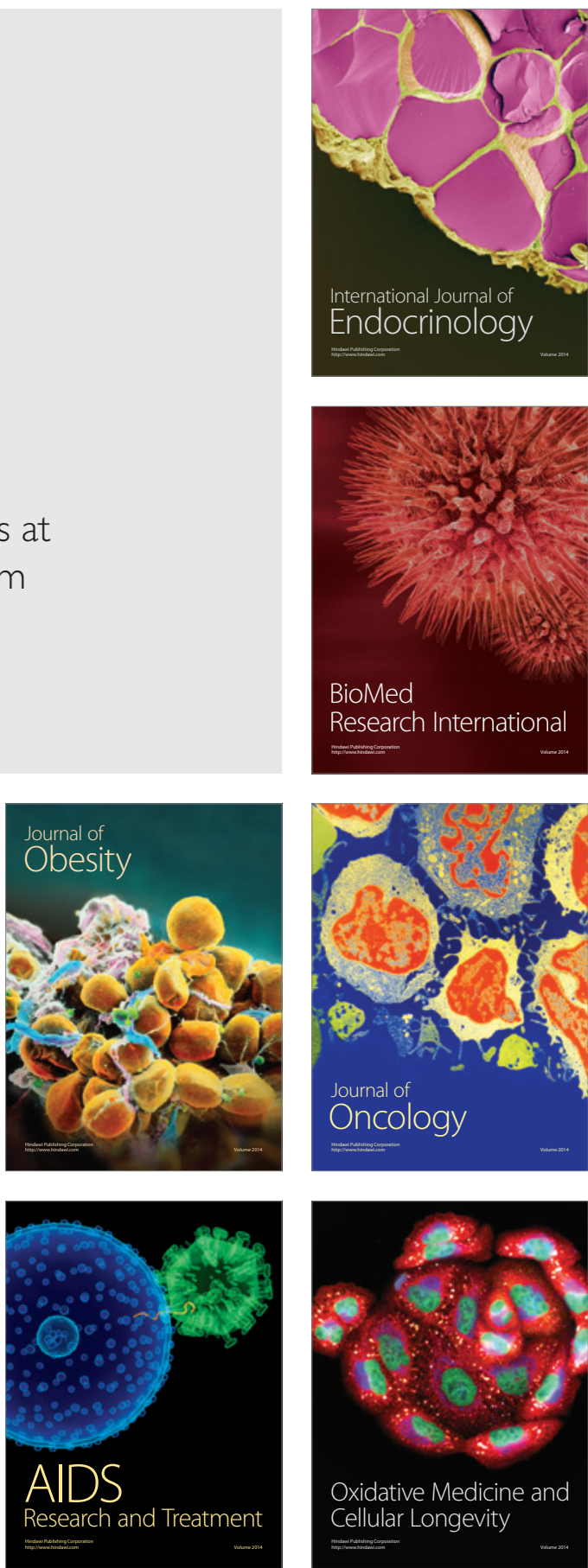